\title{
Pra Desain Pabrik Asam Sulfat dari Belerang Dengan Proses Doubel Kontak Doubel Absorber
}

\author{
Muhammad Luqman Hakim, Ferry Ida Nur Aini, Nuniek Hendrianie, Sri Rachmania Juliastuti \\ Departemen Teknik Kimia, Fakultas Teknologi Industri, Institut Teknologi Sepuluh Nopember (ITS) \\ e-mail:nuniek@chem-eng.its.ac.id
}

\begin{abstract}
Abstrak-Bahan penunjang yang sangat penting dan banyak dibutuhkan industri kimia. Bahan baku untuk produksi asam sulfat didapat dari tambang belerang dari Gunung Ijen, Jawa Timur. Katalis untuk menunjang pembuatan asam sulfat adalah Vanadium Pentaoksida $\left(\mathrm{V}_{2} \mathrm{O}_{5}\right) . \mathrm{H}_{2} \mathrm{SO}_{4}$ menggunakan proses Double Kontak Double Absorb. Pabrik direncanakan berkapasitas 247.777 ton/tahun, dimana pabrik akan beroperasi selama 24 jam sehari, 350 hari operasi. Proses pembuatan asam sulfat dengan proses Double Contact Double Absorb ada 4 tahap. Tahap pertama adalah persiapan bahan baku dimana sulfur granular di cairkan dalam melter berpengaduk menjadi sulfur cair. Tahap kedua adalah pembentukan gas $\mathrm{SO}_{2}$ dimana sulfur cair dipompakan ke sulfur burner untuk dibakar dengan fuel gas dan udara kering. Reaksi tahap ke 2 yaitu : $\mathrm{S}+\mathrm{O}_{2} \rightarrow \mathrm{SO}_{2}-70,96.10^{3} \mathrm{Kcal} / \mathrm{kmol}$.

Tahap ketiga yaitu proses kontak pertama untuk pembentukan gas $\mathrm{SO}_{3}$ dimana gas $\mathrm{SO}_{2}$ hasil pembakaran dikonversikan kedalam converter melalui 3 bed dengan bahan penunjang katalis vanadium pentaoksida, hasil konversi gas $\mathrm{SO}_{3}$ sebesar $98,5 \%$. Reaksi tahap ke 3 yaitu :

$\mathrm{SO}_{2}+1 / 2 \mathrm{O}_{2} \rightarrow \mathrm{SO}_{3}-23,49.10^{3} \mathrm{Kcal} / \mathrm{kmol}$

Tahap keempat yaitu Absorbsi gas $\mathrm{SO}_{3}$ dan Drying Air dimana gas $\mathrm{SO}_{3}$ hasil konversi diabsorb di absorber tower I menggunakan media pengabsorb kandungan air dalam $\mathrm{H}_{2} \mathrm{SO}_{4}$ 98,5\% menjadi produk $\mathrm{H}_{2} \mathrm{SO}_{4}$, produk diparalel ke Drying Tower untuk pembuatan udara kering dengan mengontakkan udara bebas dengan $\mathrm{H}_{2} \mathrm{SO}_{4}$ kemudian kandungan air dalam udara bebas diserap, Gas $\mathrm{SO}_{3}$ yang gagal terabsorb di absorber tower I diumpankan ke converter bed 4 kemudian diabsorb di absorber tower II, produk $\mathrm{H}_{2} \mathrm{SO}_{4}$ kemudian didinginkan dan disimpan di Storage Tank. Reaksi tahap ke 4 yaitu : $\mathrm{SO}_{3}+\mathrm{H}_{2} \mathrm{O} \quad \mathrm{H}_{2} \mathrm{SO}_{4}-32,8 \mathrm{kcal} / \mathrm{kmol}$
\end{abstract}

Kata Kunci-Asam Sufat, Belerang, proses kontak

\section{PENDAHULUAN}

$I^{N}$ NDONESIA merupakan negara berkembang dengan tingkat pertumbuhan industri yang tinggi. Perkembangan teknologi saat ini mengakibatkan semakin pesatnya perkembangan industri kimia di dunia termasuk juga di Indonesia. Perkembangan industri ini juga diiringi dengan peningkatan konsumsi masyarakat terhadap produk-produk industri. Produk-produk industri kimia saat ini telah menjadi kebutuhan hampir di semua bidang kehidupan sehari-hari. Pembudidayaan tumbuhan dan hewan memerlukan pupuk kimia, pakan (makanan hewan), insektisida, pestisida, herbisida dan desinfektan. Kementerian Perindustrian Indonesia saat ini berkomitmen untuk memberikan prioritas bagi pengembangan industri kimia dan logam melalui upaya strategis meningkatkan daya saing serta pertumbuhan industri dalam negeri. Asam sulfat merupakan salah satu bahan penunjang yang sangat penting dan banyak dibutuhkan industri kimia. Kegunaan utama $(60 \%$ dari total produksi di seluruh dunia) as am sulfat adalah dalam produksi as am fosfat, yang digunakan untuk membuat pupuk fosfat, penyulingan minyak bumi, manufaktur bahan peledak, farmasi, deterjen, plastik, kertas dan pulp. Mengingat pentingnya asam sulfat, maka kebutuhan negara terhadap asam sulfat dapat dijadikan salah satu tolak ukur kemajuan industri negara tersebut. Bahan baku untuk produksi asam sulfat yaitu batuan belerang, diperoleh melalui pertambangan belerang yang terdapat di 2 pegunungan Jawa Timur yaitu, Welirang dan Ijen. Data Kementrian Energi dan SDM pada tahun 2010 menyebutkan bahwa kandungan belerang di masing-masing lokasi tersebut diperkirakan lebih dari 24.500 ton/tahun-nya yang berhasil ditambang oleh pekerja secara manual di area tersebut. Data statistik yang dihimpun oleh Commodity Trade Statistics Database (CTSD) dibawah naungan United Nations Statistcs division pada interval tahun 2011-2015 menyebutkan bahwa total impor asam sulfat oleh negara Indonesia cukup tinggi dan memiliki margin yang sangat besar dibandingkan ekspor negara Indonesia ke luar negeri. Pada tahun 2015 kemenperin menyebutkan nilai impor as am sulfat sebesar USD 17.239.546 sedangkan nilai ekspor nya USD 96 saja. Oleh karena itu, peluang untuk memasuki pasar asam sulfat masih terbuka lebar.

\section{URAIAN PROSES}

Proses pembuatan Asam Sulfat pada pabrik ini menggunakan proses hidrogenasi katalitik. Pembuatan Asam Sulfat dengan hidrogenasi katalitik ini terdiri dari beberapa unit proses yaitu :

1. Preparation Unit (Sulphur Handling)

2. $\mathrm{SO}_{2}$ Generation

3. $\mathrm{SO}_{2}$ Convertion

4. $\mathrm{SO}_{3}$ Absorbtion

Proses tersebut terdiri dari tahap-tahap tersendiri dan memiliki unit operasi tersendiri sesuai dengan fungsi dari unit tersebut. Secara garis besar proses tersebut dapat digambarkan dengan flowchart berikut:

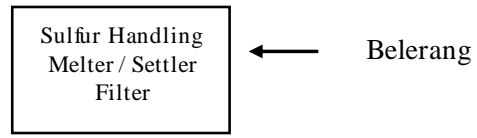




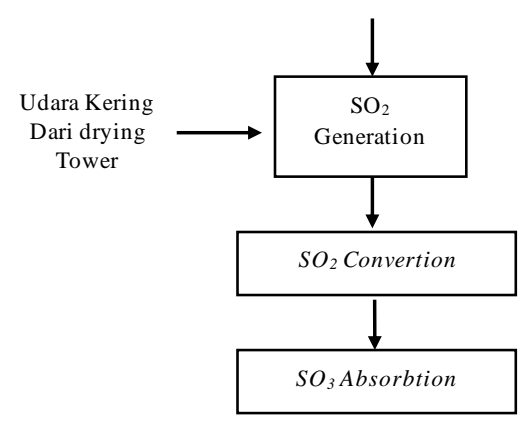

Gambar 1. Blok Diagram Skema Proses Pembuatan Asam Sulfat

\section{A. Persiapan Bahan Baku}

Jenis sulfur yang digunakan adalah sulfur dari pegunungan belerang di kawah ijen. Dari tempat ini sulfur diangkut dengan truk untuk d bawa ke pabrik dan di tampung ke dump hopper.

\section{B. Tahap Silfur Handling}

Belerang masuk pada crusher untuk mengecilkan ukuran dan dimasukkan ke melter menggunakan conveyor. Sulfur dicairkan dengan pemanas steam (steam coil) yang dilengkapi dengan agitator. Waktu yang digunakan untuk mengendapkan kotoran yang terkandung dalam sulfur disettling pit adalah 48 jam sehingga hanya sulfur bersih yang masuk ke dirty sulphur pumping pit. Sulfur cair kemudian dipompakan ke sulphur filter. Untuk mencairkan sulfur di melter digunakan steam yang bertekanan $7 \mathrm{~kg} / \mathrm{cm}^{2}$ dan untuk menjaga keadaan sulfur tetap cair diperpipaan digunakan steam jacket dengan tekanan steam sebesar 4 $\mathrm{kg} / \mathrm{cm}^{2}$. Untuk menjaga sulfur tetap cair temperatur dijaga $135^{\circ} \mathrm{C}$. Viskositas sulfur cair akan menurun dengan kenaikan temperatur, viskositas minimum dicapai pada temperatur $153^{\circ} \mathrm{C}$. Pada temperatur di atas $153^{\circ} \mathrm{C}$ viskositas sulfur akan naik dengan cepat. Kondensat steam dari jacket dikumpulkan dan ditampung untuk digunakan lagi.

\section{C. $\mathrm{SO}_{2}$ Generation}

Sulfur cair yang bersih dari storage tank dialirkan ke dalam sulphur burner feed pit yang dibangun di bawah tanah dan dilengkapi steam coil pemanas. Pit ini dilengkapi juga dengan pompa sulfur tipe vertikal, burner feed pump yang mana pompa ini memompa sulfur cair ke sulphur furnace dengan tekanan sekitar $10 \mathrm{~kg} / \mathrm{cm}^{2}$. Laju alir sulfur cair ke furnace dapat diatur dengan control valve. Sulfur cair yang masuk ke sulphur furnace di-spray-kan melalui sulphur burner dan direaksikan dengan udara kering dari drying tower menjadi gas $\mathrm{SO}_{2}$ dengan reaksi sebagai berikut:

$$
\mathrm{S}+\mathrm{O}_{2} \rightarrow \mathrm{SO}_{2}-70,96.10^{3} \mathrm{Kcal} / \mathrm{kmol} \text {. }
$$

Pembakaran yang sempurna dimaksudkan untuk melindungi pemanasan setempat dari refractory dan penguapan sulfur serta pembentukan NOx. Gas proses panas yang mengandung $\mathrm{SO}_{2}$ dengan konsentrasi sekitar $10,5 \%-\mathrm{v}$ didinginkan secara tepat di dalam WHB dan steam superheater yang mana steam yang diproduksi adalah superheater steam. Temperatur gas outlet furnace sekitar $1042^{\circ} \mathrm{C}$ dan outlet $\mathrm{WHB} 593^{\circ} \mathrm{C}$. WHB dilengkapi dengan by pass gas untuk menjaga temperatur gas inlet converter.

\section{D. $\mathrm{SO}_{2}$ Convertion}

Converter terdiri dari empat bed. Tiga bed merupakan konverter tingkat pertama dan bed keempat merupakan konverter tingkat kedua. Setiap tingkat konversi masingmasing mempunyai absorber. Gas proses yang mengandung gas $\mathrm{SO}_{2}$ dengan temperatur $430^{\circ} \mathrm{C}$ masuk ke converter bed dimana sekitar $60 \%$ dari gas $\mathrm{SO}_{2}$ diubah menjadi $\mathrm{SO}_{3}$ dengan katalis $\mathrm{V}_{2} \mathrm{O}_{5}$ dan reaksi sebagai berikut :

$\mathrm{SO} 2+1 / 2 \mathrm{O} 2 \quad \mathrm{SO} 3-23,49.10^{3} \mathrm{Kcal} / \mathrm{kmol}$

Gas outlet bed I yang mengandung $\mathrm{SO}_{3}$ dengan temperatur $611^{\circ} \mathrm{C}$ masuk $\rightarrow$ se heat exchanger I yang mana panasnya diberikan kepada gas yang akan masuk ke bed IV. Gas dari bed I kemudian masuk ke bed II dengan temperatur $440^{\circ} \mathrm{C}$ untuk konversi selanjutnya.

Gas outlet bed II dengan temperatur $521^{\circ} \mathrm{C}$ masuk ke heat exchanger II dan selanjutnya keluar pada temperatur $430^{\circ} \mathrm{C}$ dan masuk ke bed III. Pada heat exchanger ini panas gas digunakan untuk memanaskan gas yang akan masuk ke bed IV.

Gas outlet bed III banyak mengandung $\mathrm{SO}_{3}$ dengan temperatur $451^{\circ} \mathrm{C}$ masuk ke economizer I untuk didinginkan hingga $220^{\circ} \mathrm{C}$ sebelum masuk absorbing tower I. Sekitar 94\% dari gas $\mathrm{SO}_{2}$ dikonversikan menjadi gas $\mathrm{SO}_{3}$ di tiga bed pertama.

Setelah gas $\mathrm{SO}_{3}$ diserap dengan $\mathrm{H}_{2} \mathrm{SO}_{4}$ di Absorber, sisa gas dengan temperatur $80^{\circ} \mathrm{C}$ melalui demister di bagian atas Absorber. Aliran gas tersebut kemudian dipisah secara paralel dan masing-masing masuk ke heat exchanger I dan II kemudian aliran gas digabung sebelum masuk bed IV.

Gas sebelum masuk bed IV dipanasi di heat exchanger I dan II. Temperatur gas naik menjadi $420^{\circ} \mathrm{C}$. Konversi terakhir ini dari double contact terjadi di bed katalis IV. Gas outlet bed IV dengan temperatur $440^{\circ} \mathrm{C}$ masuk ke dalam economizer II untuk didinginkan hingga $190^{\circ} \mathrm{C}$ sebelum masuk absorbing tower II. Untuk mencegah kondensasi gas dari gas outlet $\mathrm{T}$ 1302, dipasang tracing pada gas duct antara dan.

\section{E. $\mathrm{SO}_{3}$ Absorbtion}

Udara atmosfer dihisap dengan air blower melalui drying tower. Pada drying tower ini kandungan air dalam udara diserap $\mathrm{H}_{2} \mathrm{SO}_{4}$ dan menghasilkan udara kering. Asam sulfat 98,5 \% disirkulasikan melalui drying tower. Udara kering dari air blower yang bertemperatur $109^{\circ} \mathrm{C}$ dimasukkan ke sulphur furnace sebagai udara pembakar untuk oksidasi sulfur. Gas yang mengandung $\mathrm{SO}_{3}$ dari bed III dan bed terakhir dari konverter diserap oleh $\mathrm{H} 2 \mathrm{SO} 4$ 98,5\% yang disirkulasikan di absorbing tower I dan II yang menghasilkan asam sulfat.

$\mathrm{SO} 3+\mathrm{H} 2 \mathrm{O} \quad \mathrm{H} 2 \mathrm{SO} 4-32,8 \mathrm{kcal} / \mathrm{kmol}$

Pengenceran $\mathrm{H}_{2} \mathrm{SO}_{4}$ selama penyerapan $\mathrm{H}_{2} \mathrm{O}$ dari udara di dalam drying tower dan penamb ahan konsentrasi dari penyerapan $\rightarrow \mathrm{SO}_{3}$ didalam absorbing tower I dicampur bersama-sama di dalam DT/1 ${ }^{\text {st }}$ AT pump tank. Apabila 
konsentrasi $\mathrm{H}_{2} \mathrm{SO}_{4}$ di dalam pump tank ini masih lebih tinggi dari $98,5 \%$, ditambahkan air (dilution water) yang tujuannya untuk menjaga konsentrasi tetap $98,5 \% \mathrm{H}_{2} \mathrm{SO}_{4}$.

\section{NERACA MASSA}

Berdasarkan hasil perhitungan neraca massa, dengan kapasitas produksi pabrik Asam sulfat sebesar 708 ton/hari, dengan Belerang yang dibutuhkan sebesar 12.111,75 kg/jam [3].

\section{ANALISA EKONOMI}

Dari hasil perhitungan pada neraca ekonomi didapatkan Total Cost Investment pabrik ini sebesar Rp 694.549.276.343 dengan bunga $10 \%$ per tahun. Selain itu, diperoleh IRR sebesar 22,29\% dan BEP sebesar 33,04\% dimana pengembalian modalnya selama 5,55 tahun. Umur dari pabrik ini diperkirakan selama 10 tahun dengan masa periode pembangunannya selama 2 tahun di mana operasi pabrik ini 330 hari/tahun [4].

\section{KESIMPULAN/RINGKASAN}

Berdasarkan hasil analisa ekonomi didapatkan nilai IRR sebesar $22,29 \%$ yang lebih tinggi dari suku bunga bank yaitu $10 \%$ per tahun, dimana pengembalian modalnya selama 5,55 tahun maka Pabrik Asam sulfat dari Belerang dengan Proses Doubel kontak doubel absorber ini layak didirikan.

\section{UCAPAN TERIMA KASIH}

Penulis mengucapkan terimakasih kepada keluarga Laboratorium Pengolahan Limbah Industri Jurusan Teknik Kimia FTI-ITS yang telah memberikan dukungan dan saran terhadap penulis an aritikel.

\section{DAFTAR PUSTAKA}

[1] Cahyadi, W. 2008. Analisis Dan Aspek Kesehatan Bahan Tambahan Pangan. Jakarta.: Bumi Aksara

[2] Markakis, P., (1987), Editor Fennema. 1996 Dalam Food Chemistry, Marcel Dekk er Inc, New York.

[3] Himmelblau, David M. Basic Principles and Calculation in Chemical Engineering. 5th edition. Prentice Hall International Inc. : Singapore.(1989).

[4] Peters, Max S. and Timmerhauss, Klaus D. Plant Design and Economics For Chemical Engineerings. 4th edition. McGraw Hill Book Co : Singapore.(1991) 